NBER WORKING PAPER SERIES

\title{
ON THE LIMITATIONS OF GOVERNMENT BORROWING: A FRAMEWORK FOR \\ EMPIRICAL TESTING
}

\author{
James D. Hamilton \\ Marjorie A. Flavin
}

Working Paper No. 1632

\section{NATIONAL BUREAU OF ECONOMIC RESEARCH 1050 Massachusetts Avenue \\ Cambridge, MA 02138 \\ June 1985}

We are indebted to Charles Engel, Ron Michener, and John Taylor for helpful comments, and to Michael Cox for generously providing us with his data. The research reported here is part of the NBER's research program in Economic Fluctuations and project in Government Budget. Any opinions expressed are those of the authors and not those of the National Bureau of Economic Research. 


\title{
On the Limitations of Government Borrowing: A Framework for Empirical Testing
}

\section{ABSTRACT}

This paper seeks to distinguish empirically between two views on the limitations of government borrowing. According to one view, nothing precludes the government from running a permanent budget deficit, paying interest due on the growing debt load simply by issuing new debt. An alternative perspective holds that creditors would be unwilling to purchase government debt un-. less the goverment made a credible commitment to balance its budget in presentvalue terms. We show that distinguishing between these possibilities is mathematically equivalent to testing whether a continuing currency inflation might be fueled by speculation alone or is instead driven solely by economic fundamentals. Empirical tests which have been developed for this economic question lead us to conclude that postwar U.S. deficits are largely consistent with the proposition that the government budget must be balanced in present-value terms.

\author{
James D. Hamilton \\ Department of Economics \\ Rouss Hall \\ University of Virginia \\ Charlottesville, VA 22901 \\ (804) $924-3178$ \\ Marjorie A, Flavin \\ Department of Economics \\ Rouss Hall \\ University of Virginia \\ Charlottesville, VA 22901
}

(804) 924-3178 


\section{Introduction.}

This paper addresses the question of whether the government budget must be balanced in present-value terms. This question holds profound implications for macroeconomic theory and practice. With a Reynesian consumption function, an affirmative answer can reverse the traditional conclusion that money-financed deficits are more expansionary than bond-financed deficits (Blinder and Solow, 1974). With a permanent-income consumption function, by contrast, it can imply that a bond-financed deficit has no effect on aggregate demand. ${ }^{1}$ And if the only politically acceptable means of raising the requisite revenues is with money creation, it can imply a strong practical link between budget deficits and inflation, as argued by Sargent (1982) and Sargent and Wallace (1981). It of course also has serious implications for measures which may be necessary to adopt in the future as a consequence of budget deficits accumulating in the United States and many developing countries.

Why do some claim that government deficits must be balanced with future surpluses? Whenever the budget goes into deficit, new debt must be issued. If this is in the form of one-period bonds, then next year interest and principal on that debt will come due. ${ }^{2}$ Accordingly, even if taxes in this following year were sufficient to cover spending on government programs, new debt would still have to be issued for that year, not only to replace the old debt which comes due, but further to cover the accumulated interest on this debt. If taxes are no greater than spending for yet a second year, then at the end of the second year outstanding debt will have grown by two years of accumulated interest. If taxes never exceed spending, debt would grow forever without bound as an infinite interest load accumulated as a conseouence of a single year's deficit. 
Whether rational households would in fact always be willing to buy this debt remains an unsettled theoretical question. If the government's borrowing cost equals or exceeds the economy's growth rate, then an unpaid deficit implies that debt must grow to become an infinite multiple of GNP. ${ }^{3}$ Such an equilibrium seems counter-intuitive, though McCallum (1984) provides an optimizing example in which both households' interest income and the tax on that interest income indeed grow to become an arbitrarily large multiple of total production. On the other hand, if the interest rate $(r)$ is less than the economy's growth rate (q), then an infinitely-lived government clearly could run a permanent deficit without having debt become a growing multiple of GNP, as stressed by Feldstein (1976) and Buiter (1984). While $r<q$ is inconsistent with an optimizing equilibrium with infinitely-lived individuals in the standard neoclassical growth model (e.g., Cass 1965 or Dixit 1976, p, 109), it does appear to be allowed in certain overlapping-generations models, ${ }^{4}$ and in models where private borrowing takes place at higher interest rates than public borrowing, e.g., if private debt is inherently riskier as in Eaton (1981). It in any case seems desirable to supplement these theoretical considerations with empirical evidence. Seater (1982) and Aschauer (1985), among others, have tested the hypothesis that the present-value budget must be balanced jointly with a permanent-income efficient-markets hypothesis, and accepted. Barro (1984b) tested the hypothesis that the present-value budget must be balanced jointly with the assumption that taxation and deficit policies have historically been optimal, and again accepted. However, to our knowledge there has been no direct empirical test of the present-value constraint itself.

Such a test might at first glance seem straight-forward enough. The United States government, for example, has run more or less a chronic deficit since 
1930, suggesting that permanent deficits are quite feasible and practical. However, this simple argument ignores the potential role of debt retirement through monetization and capital gains on bonds or tangible assets through inflation. It further provides no formal test of whether these deficits were rationally anticipated, nor allowance for what might rationally be expected to happen out of sample.

In this paper we propose an empirical framework for testing the practical limits to public borrowing which gets around these criticisms. We show that the proposition that the government can accumulate ever-growing debt through perpetual deficit-financing is mathematically equivalent to the proposition that prices can rise continually in a self-fulfilling speculative bubble, Thus, empirical tests which have been developed for the latter hypothesis may also be fruitfully applied to study the limits of government borrowing.

Section 2 provides a formal statement of the present-value constraint to be tested. Section 3 briefly discusses some issues of data and measurement. In Section 4 we present the results of alternative empirical tests of whether the postwar record of budget deficits in the United States could be consistent with the present-value constraint under rational expectations, with brief conclusions offered in Section 5.

2. The present-value government borrowing constraint.

In the light of the disparate concepts of the correct measurement of real government indebtedness prevalent in the literature (e.g., Jump 1980, Buiter 1983, Barro 1984a, and Eisner and Pieper 1984), it seems worthwhile to develop from first principles the expression appropriate for the tests proposed in this paper. One difficulty arises because at any time the public holds government 
securities of a variety of terms and vintages. To understand the budget implications of capital gains and losses on these different issues, we allow each dollar of debt potentially to have its own unique characteristics. Let the integer $\mathrm{J}_{t}$ denote the nominal face value of interest-bearing govermment debt at the end of period $t$, which we may think of as a collection of $J_{t}$ different $\$ 1$ face-value bonds, Let $b_{j, t}\left(j=1,2, \ldots, J_{t}\right)$ denote the nominal market value of the $j^{\text {th }}$ (face value) dollar of debt, and $\theta_{j, t}$ its coupon paid between dates $t-1$ and $t$. We further let $P_{t}$ denote an aggregate price index for goods in the economy and $\bar{r}$ the associated ex post real interest rate which is earned on one-period goverment bonds during an average year. Finally, we define $v_{j, t}$ to be the real excess one-period holding yield of bond $j$ relative to the average earned on one-period bonds:

$$
v_{j, t} \equiv \frac{b_{j, t}+\theta_{j, t}}{P_{t}}-\frac{(1+\bar{r})_{j, t-1}}{P_{t-1}}
$$

which implies

$$
\frac{b_{j, t}}{P_{t}} \equiv \frac{(1+\bar{r})_{j, t-1}}{P_{t-1}}-\frac{\theta_{j, t}}{P_{t}}+v_{j, t} .
$$

of course, not all these bonds are held by the public, and the quantity held by the public will increase or decrease in part as they are sold or purchased by the Federal Reserve. Suppose that at the end of period $t-1$ the first $L_{t-1}$ bonds are held by the Fed and the remaining $J_{t-1} I_{t-1}$ held by the public. Consider an open market purchase during period $t$ that acquires the next $L_{t}-L_{t-1}$ bonds: 


$$
\sum_{j=L_{t-1}+1}^{L_{t}} b_{j, t}=M_{t}-M_{t-1}+u_{1, t}
$$

where $M_{t}$ denotes the stock of high-powered money at the end of period $t$, In principle, equation (3) might be thought of as an accounting identity characterizing open-market operations. As a practical issue, however, we must append the measurement error term $u_{1 t}$, since open-market purchases near the beginning of period $t$ would actually take place at market prices closer to $b_{j, t-1}$, and since serious data difficulties arise in keeping track of the true market value of all the assets in the Fed's portfolio.

Additionally, some number of new bonds (say, $J_{t} J_{t-I}$ ) might be issued during period to cover any budget deficit, and these of course are likewise initially issued at market value;

$$
\sum_{j=J_{t-1}+1}^{J}\left(b_{j, t} / P_{t}\right)=G_{t}+R_{t}-T_{t}+u_{2, t} \text {. }
$$

Here $G_{t}$ denotes real government purchases of goods, $R_{t}$ real interest expenditures, ${ }^{5}$ and $T_{t}$ real tax revenues, Once again, measurement error $u_{2, t}$ is introduced by issues of within-period timing of new debt issue and by the impossibility of accurately measuring the true market value of net government indebtedness.

$$
\begin{aligned}
& \text { Equations (2), (3) and (4) imply } \\
& \sum_{j=L_{t}+1}^{J_{t}} \frac{b_{j, t}}{P_{t}}=\sum_{j=L_{t-1}+1}^{J_{t-1}} \frac{(1+\bar{r}) b_{j, t-1}}{P_{t-1}}-\sum_{j=L_{t-1}+1}^{J_{t-1}} \frac{\theta_{j, t}}{P_{t}}+\sum_{j=L_{t-1}+1}^{J} v_{j, t} \\
& +G_{t}+R_{t}-T_{t}-\frac{\left(M_{t}-M_{t-1}\right)}{P_{t}}-\frac{u_{1, t}}{P_{t}}+u_{2, t} \cdot
\end{aligned}
$$


Next, define $B_{t}$ to be the nominal market value of debt held by the public, i.e., $B_{t}=\sum_{j=L_{t}+1}^{J} b_{j, t}$. Notice also $R_{t}=\sum_{j=L_{t=1}+1}^{J-1}\left(\theta_{j, t} / P_{t}\right)+u_{3, t}$. Finally, let $S_{t}$ denote the real goverment surplus in year $t$ (including money seignorage but excluding interest payments):

$$
S_{t} \equiv T_{t}+\frac{\left(M_{t}-M_{t-1}\right)}{P_{t}}-G_{t}
$$

and let $V_{t}$ denote the combined influence of time-varying real interest rates, capital gains and losses on government bonds, and measurement error:

$$
v_{t} \equiv \sum_{j=L_{t-1}+1}^{J-1} v_{j, t}-\left(u_{1, t} / P_{t}\right)+u_{2, t}+u_{3, t} \text {. }
$$

Then equation (5) may be written;

$$
\frac{B_{t}}{P_{t}}=\frac{(I+\bar{r}) B_{t-1}}{P_{t-1}}-S_{t}+V_{t}
$$

By recursive substitution forwards, equation ( 8 ) is seen to imply

$$
\frac{B_{t-1}}{P_{t-1}}=\sum_{i=1}^{N} \frac{\left(S_{t+i-1}-v_{t+i-1}\right)}{(1+\bar{r})^{i}}+\frac{B_{t+i-I}-}{P_{t+N}(\bar{T}+\bar{r})^{N}} \text {. }
$$

Equation (8) and its implication (9) can not be a point of serious controversy, for they do little more than summarize the equations of motion characterizing monetary and fiscal policy. What is of economic interest (and subject in principle to empirical refutation) is what happens to the second term in (9) as $\mathrm{N}$ gets large. This term registers whether the supply of bonds held by the public grows faster on average than the rate of interest. It accordingly reflects the feasibility of the government running a permanent budget deficit, paying in- 
terest on the growing debt load simply by issuing new debt. In this paper we are therefore interested in testing

$$
E_{0}: \lim _{N \rightarrow \infty} \frac{B_{t+N}}{P_{t+N}(1+\bar{r})^{N}}=0
$$

or equivalently

$$
B_{0}: \frac{B_{t}}{P_{t}}=\sum_{i=1}^{\infty} \frac{\left(S_{t+i}-V_{t+i}\right)}{(1+\bar{r})^{i}} \text {. }
$$

Buiter (1984) calls (10) the "present value budget constraint," while West's (1984) study of stock price volatility refers to a condition analogous to (10) as the "transversality condition." Note that condition (10) does not imply that "the national debt would eventually be paid off" (e.g., Dornbusch and Fischer, 1984, p. 525). In fact, (10) is consistent with a constantly increasing stock of debt, as long as the rate of increase is less than the government 's borrowing rate. Rather, the question we pose is whether interest on this debt is to be paid with future tax increases or instead with continual issue of new debt. If (10) represents the null hypothesis that the government budget must be intertemporally balanced, how may we usefully frame the alternative possibility that government deficits could continue forever? The answer to this question is obtained by now solving equation (8) backwards to get:

$$
B_{t} / P_{t}=(1+\bar{r})^{t}\left(B_{o} / P_{o}\right)+\sum_{j=1}^{t}(1+\bar{r})^{t-j}\left(v_{j}-s_{j}\right) \text {. }
$$

In what follows we assume that the infinite sum

$$
\sum_{j=1}^{\infty}(1+\bar{r})^{-j}\left(s_{j}-v_{j}\right)
$$


converges. Note this assumption makes sense even when debt itself $(1+\bar{r})^{-N}\left(B_{t+N}{ }^{\prime}\right.$ $\left.P_{t+N}\right)$ does not converge, because by definition $S_{t}$ excludes the ballooning interest payments on this debt. Adding and subtracting $(1+\bar{r})^{t}$ times expression (12) to the right-hand side of (11) yields

$$
\left(B_{t} / P_{t}\right)=(I+\bar{r})^{t}\left(B_{o} / P_{0}-\sum_{j=1}^{\infty}(I+\bar{r})^{-j}\left(S_{j}-V_{j}\right)\right)+\sum_{j=t+1}^{\infty}(1+\bar{r})^{t-j}\left(S_{j}-v_{j}\right)
$$

or

$$
B_{t} / P_{t}=A_{0}(1+\bar{r})^{t}+\sum_{j=1}^{\infty}(1+\bar{r})^{-j}\left(S_{t+j}-V_{t+j}\right)
$$

where $A_{0} \equiv B_{0} / P_{0}-\sum_{j=1}^{\infty}(1+\bar{r})^{-j}\left(S_{j}-V_{j}\right)$. Comparing equation (13), which is the completely general solution to the difference equation (8), to (10b), the restricted solution under the hypothesis $\mathrm{H}_{\mathrm{O}}$ that the government budget must be balanced in present-value terms, we observe the following:

$\mathrm{H}$ is true if and only if $\mathrm{A}=0$ in equation (13).

Equation (13) is mathematically equivalent to models used to study selffulfilling fads or speculative bubbles first explored by Flood and Garber (1980). We accordingly propose that such tests might also be fruitfully applied to understanding the limits of government borrowing. The next section discusses the data on which such tests might be based, while section 4 summarizes our results.

3. Issues of data and measurement.

Eisner and Pieper (1984) and Barro (1984a) bave shed substantial light on the relation between officially reported budget figures and the appropriate measures of true economic interest, Here we briefly discuss how the theoretical magnitudes appearing in our equation (13) are related to the budget figures 
actually reported in the United States, Complete details on data sources and methods used in our study are available in a data appendix available from the authors on request.

a. Interest payments.

The theoretical measure of govermment spending $\left(G_{t}\right)$ in the above derivation excludes outlays for interest expenditures. Correcting the officially reported surplus $\left(\hat{T}_{t}-\hat{G}_{t}\right)$ to exclude interest payments requires three steps. (1) Add to $\left(\hat{T}_{t}-\hat{G}_{t}\right.$ ) total interest payments (some $\$ 28.1$ B for fiscal year

1974). (2) For data prior to 1982 , subtract back out that part of this Treasury interest (some $\$ 6.6 \mathrm{~B}$ in FY 1974) that was paid directly into federal government trust funds such as social security, (Prior to 1982, this sum was already included as an expenditure offset in the officially reported surplus, and accordingly would be counted twice if we just added total reported interest payments to $\hat{T}_{t}-\hat{G}_{t}$. After 1982, it has furthermore already been subtracted before reporting the total interest figure, so just adding the reported interest figure to $\hat{T}_{t}-\hat{G}_{t}$ in this case gives the correct measure.) (3) Likewise subtract the deposit of Federal Reserve earnings (some $\$ 4.8$ B in FY 1974), which again are already included in $\hat{\mathrm{T}}_{t}$ under miscellaneous receipts. A sample calculation is provided in Table 1, with details for each fiscal year in the data appendix.

Some debt is issued by various federal agencies in addition to that issued by the Treasury. Outlays for the service of such debt are presently included as expenditures of that agency, and should be subtracted from $\hat{G}_{t}$ to arrive at our measure of $G_{t}$. Unfortunately, such data are not readily available. Since agency debt is small (e.g., \$12 B in 1974 compared with $\$ 475$ B in Treasury debt), little harm can come from assuming that the present value relation holds 
for agency debt, in which case we could approximate the present value of later agency interest payments by the current market value of new agency debt issue. Thus, we subtract new issue of agency securities ( $\$ 0.9$ B in FY 1974) from $\hat{G}_{t}$, and do not count the market value of agency securities in our measure of public holdings of government debt, $B_{t} \cdot 6$

b. Trust funds.

In the unified budget system used in the U,S. since 1969 (and extended retroactively to 1959), two separate accounts are maintained, Federal funds are general purpose revenues and programs. Trust funds collect specified taxes and spend on specified programs such as social security,

In FY 1974, the Federal funds deficit was $\$ 17.4 \mathrm{~B}$, whereas the Trust funds surplus was $\$ 14.0 \mathrm{~B}$. The difference, $-\$ 3.4 \mathrm{~B}$, is the deficit officially reported for FY 1974. This is obviously the correct concept, and needs to be extended to debt accounting as well. Treasury debt went up from $\$ 457.3 \mathrm{~B}$ at the end of FY 1973 to $\$ 474.2$ B at the end of FY 1974, but clearly this does not represent an equivalent increase in net government indebtedness, since most of these new bonds were simply held by a different branch of the government. The correct measure would subtract the stock of investments in government accounts $(\$ 140.2 \mathrm{~B}$ at the end of FY 1974) from total Treasury debt.

Some might argue that these Trust fund holdings are to be used against the government's liabilities implied by future social security benefit payments. It seems to us that this is an inaccurate interpretation, Such programs are not a current liability in the sense that they can be associated with any concrete number. Rather, they represent the outcome of an uncertain political process, 
and the correct way to represent this "liability" is by the discounted cash flow of an entry on current account rather than any dubious imputation to capital account. That is, we follow the official accounts in registering net social security Inflows or outflows on the deficit account, and not as figures imputed to the debt itself.

c. Off-budget items.

Starting in 1971 , the activities of certain agencies such as the Postal Service Fund and Rural Electrification and Telephone Revolving Fund are characterized as "off-budget." 7 Any deficits of such operations require the issue of Treasury bonds, though they do not count in the officially measured deficit of the U.S, government.

Suppose that these funds were indeed primarily conveyors of sound loans. Imagine the agency issuing a \$1 loan financed through a \$1 sale of Treasury bonds, and so running an off-budget $\$ 1$ deficit for that year. In the following year, the agency receives $\$ r$ as interest payments from the private sector, but the Treasury pays $\$ r$ back to the public as interest on the $T$-bond. For this year, the official budget and off-budget items would accordingly sum to a zero net deficit. Thus, a net intertemporal deficit would be measured if one combined the official budget and off-budget items into a single account, whereas the operation itself is clearly fiscally neutral - the government issued a $\$ 1$ Treasury bond but acquired a $\$ 1$ private bond, and has simply sqapped like assets with the public. A correct measure would be obtained in this case if we adopt our convention of excluding Treasury interest payments from $G_{t}$ and simply ignore the off-budget surplus or deficit altogether. 
Of course, these programs are not pure market loans but in fact have a substantial subsidy aspect. Our only justification for ignoring this is that it is difficult to quantify and presumably small relative to the complete budget.

\section{d. Tangible assets.}

Eisner and Pieper (1984) have begun the difficult task of quantifying the market value of various tangible assets owned by the government. The question for purposes of the present study is, do government bond-holders believe that future interest payments will really be met through sale of such assets rather than by more conventional means such as tax revenues or debt retirement through monetization? One's position on this question is perhaps a matter of taste as much as anything else, Our own view is that, with one important exception, the promise of substantial liquidation of government tangible assets is not a politically credible backing for U.S. Treasury debt, and should not realistically be expected to substitute for future tax revenues or money seignorage.

The one exception is the government's gold holdings. There is abundant historical evidence that governments willingly draw down or deplete these stocks in the wake of fiscal crises; this indeed is presumably the primary purpose of holding such stocks in the first place. To see the budget implications of such gold sales, let $\mathrm{Au}_{t}$ denote government's gold holdings in ounces, $\mathrm{P}_{t}^{\mathrm{Au}}$ the price per ounce of gold, and $B_{t}$ the nominal market value of debt, all measured at the beginning of period $t$. Let $S_{t}$ denote the correctly measured surplus during period $t$ (excluding interest payments from spending but making no correction for gold flows), and let $i_{t}$ be the one-period interest rate, which for simplicity we assume is the same for all bonds. If at the end of period the government sells off some amount of gold $\left(\mathrm{Au}_{t}-\mathrm{Au}_{t+1}>0\right)$ at price $\mathrm{P}_{t+1}^{\mathrm{Au}}$ and uses the 
proceeds to retire debt, then next period's debt will be given by

$$
B_{t+1}=\left(1+i_{t}\right) B_{t}-s_{t}-\left(A u_{t}-A u_{t+1}\right) P_{t+1}^{A u}
$$

which can be written as

$$
\left(B_{t+1}-P_{t+1}^{A u} A u_{t+1}\right)=\left(1+i_{t}\right)\left(B_{t}-P_{t}^{A u_{A u}}\right)+\left(i_{t}-\pi_{t}^{A u}\right) P_{t}^{A u_{A u}}-s_{t}
$$

where $\pi_{t}^{A u} \equiv\left(P_{t+1}^{A u}-P_{t}^{A u}\right) / P_{t}^{A u}$. Thus, if we define true government indebtedness as the stock of Treasury debt held by the public less the current market value of the government's gold holdings (i.e., as $B_{t}-P_{t}^{A u^{A} u_{t}}$ ), the equation governing the evolution of true government indebtedness is obtained by subtracting ( $\left.i_{t}-\pi_{t}^{A u}\right) P_{t}^{A u_{A u}}$ from the officially measured surplus $\left(\hat{T}_{t}-\hat{G}_{t}\right)$. (Note, however, that revenues should not include changes in the gold stock, i.e., ignore $\mathrm{Au}_{t+1}-\mathrm{Au}_{t}$ in calculating $\left.\mathrm{T}_{t}-\mathrm{G}_{t}\right)$.

For fiscal year 1974, gold prices increased by $17,16 \%$, whereas the nominal interest rate on one-year government bonds was $7.56 \%$. Based on a market value of the government's gold holdings of $\$ 33.8 \mathrm{~B}$, a sum of $(.1716-.0756)(33.8)$ $=\$ 3.2$ B should be added to the surplus for FY 1974 to represent capital gains from gold.

e. Money seignorage.

When the Federal Reserve acquires a bond, future interest payments on that bond accrue to the Fed and are counted as part of tax revenues under 'Miscellaneous Receipts" in the official budget. Since the present value of this tax benefit is equal to the Fed's initial cost of the bond, seignorage is in this sense theoretically already included in the budget. In practice, however, any finite-sample estimate of the discounted value of these miscellaneous receipts must be less than the discounted value of ${ }_{t+i}-M_{t+i-1}$, because open market purchases at the end of the sample period have not yet been amortized. For this 
reason, we exclude deposits of Fed interest from our measure of $T_{t}$ and include the seignorage measure $\left(M_{t}-M_{t-1}\right)$, where $M_{t}$ denotes high-powered money (the sum of currency in circulation plus reserves in member banks).

f. Other adjustments.

Painstaking calculations of the true market value of government debt, based on actual market quotations of outstanding securities, have been provided by Seater (1981) and Cox and Hirschhorn (1983) and updated by Cox (1985). At the end of FY 1974, outstanding goverment debt was trading at a market value of only $95 \%$ of its par value.

We also need to subtract Federal Reserve assets from our measure of the goverment debt. Since these are all carried on the books at par value, the simplest way to construct the correct measure closer to market value of these assets is from the liabilities side, namely, by sub tracting high-powered money from outstanding government debt to get a measure of net interest-bearing debt held by the public.

Finally, the Treasury operating cash balance and market value of gold holdings must be subtracted to arrive at the figure $B_{t}$ appearing in equation (8). Sample calculations for the 1974 deficit and debt are provided in Table 1. Table 2 details the actual series used in the calculations to follow.

\section{Empirical tests.}

We are interested in the question of whether the U.S, government's creditors could rationally expect that the government budget would be balanced in present-value terms. In the light of the discussion of section 2 , we interpret this as the restriction $A_{0}=0$ in the formulation 


$$
B_{t} / P_{t}=A_{0}(I+\bar{r})^{t}+E_{t} \sum_{j=1}^{\infty}(I+\bar{r})^{-j} S_{t+j}+n_{t}
$$

where $B_{t} / P_{t}$ and $S_{t}$ are the adjusted debt and surplus series reported in Table 2 and $n_{t}$ is a regression disturbance term reflecting expected changes in real short-term interest rates, the term structure of long rates, and measurement error. The operator $E_{t}$ denotes the expectations of creditors, which we assume are formed rationally.

Equation (14) is mathematically equivalent to the model proposed by Flood and Garber (1980) for studying self-fulfilling hyperinflations. However, Hamilton and Whiteman (1984) expand on Flood and Garber's caution that their technique implicitly imposes strong restrictions on the variables used by agents in forming expectations $E_{t}$ or on the dynamics allowed for $n_{t}$, and note that a more general test should first be considered ${ }^{8}$ which is more robust with respect to such restrictions. In particular, for any stationary process for $\left(n_{t}, E_{t} \sum_{j=1}^{\infty}(1+\bar{r})^{-j} S_{t+j}\right)$, when $A_{0}=0, B_{t} / P_{t}$ will be stationary, whereas for $A_{0}>0, B_{t} / P_{t}$ will not be stationary. We accordingly initially examine two simple tests.

(1) Dickey-Fuller test for unit roots. Dickey and Fuller (1979, p. 431) suggest the following test of the nu1l hypothesis that a series $z_{t}$ is nonstationary with unit roots. Estimate

$$
z_{t}-z_{t-1}=\theta_{0}+\theta_{1} z_{t-1}+\theta_{2}\left(z_{t-1}-z_{t-2}\right)+e_{t}
$$

by ordinary least squares, and calculate $\hat{\theta}_{1} / \hat{\sigma}_{1}$ where $\hat{\sigma}_{1}$ is the ols standard error for $\hat{\theta}_{1}$. The null hypothesis (nonstationarity) says this statistic should be zero; the alternative (stationarity) says less than zero.

Using the data in Table 2 we estimated the following equation by ols for 
$t=1962$ to 1984 (standard errors in parentheses):

$$
\begin{aligned}
& s_{t}-s_{t-1}=\underset{(3.27)(0.24)}{-0.53}-\underset{(0.24)}{0.70 s_{t-1}}+\underset{\left(0.38\left(s_{t-1}-s_{t-2}\right)\right.}{0.0 .04} \\
& \mathrm{~B}_{t} / \mathrm{P}_{t}-\mathrm{B}_{t-1} / \mathrm{P}_{t-1}=79.63-0.48 \mathrm{~B}_{t-1} / \mathrm{P}_{t-1}+1.02\left(\mathrm{~B}_{t-1} / \mathrm{P}_{t-1}-\mathrm{B}_{t-2} / \mathrm{P}_{t-2}\right) \\
& (28.13) \quad(0.17) \quad(0.22)
\end{aligned}
$$

The Dickey-Fuller test statistics are -2.92 in the case of the surplus and -2.82 in the case of debt, to be compared with a $5 \%$ critical value of -3.00 and $10 \%$ value of -2.63 reported in Table 8.5 .2$, p. 373 of Fuller (1976). The data thus favor rejection of the null hypothesis of nonstationarity in both cases; that is, the data seem fully compatible with the assertion that investors rationally expected the budget to be balanced in present value terms.

(2) Generalized Flood-Garber test. If expectations of future surpluses are conditioned in part on past surpluses and if we include lagged debt to eliminate the serial correlation of the resulting error term, then equation (14) takes the form

$$
\begin{aligned}
B_{t} / P_{t}=c_{0} & +A_{0}(1+\bar{r})+c_{1}\left(B_{t-1} / P_{t-1}\right)+\ldots+c_{p}\left(B_{t-p} / P_{t-p}\right) \\
& +b_{0} S_{t}+b_{1} S_{t-1}+\ldots+b_{p-1} s_{t-p+1}+\varepsilon_{t} .
\end{aligned}
$$

If one were willing to impose stronger restrictions on the dynamics of $\mathbf{n}_{t}$ and on the information set used by creditors, then one would want to estimate (15) jointly with cross-equation restrictions on the process followed by $S_{t}$, as in Flood and Garber's (1980) study of money demand, In the absence of such restrictions, Hamilton and Whiteman (1984) show that the coefficients $c_{j}, b_{j}$ are unrestricted, and a more general test of $\mathrm{H}_{0}$ is obtained by simple oLs ${ }^{9}$ estimation of (15): 


$$
\begin{aligned}
& \mathrm{B}_{t} / \mathrm{P}_{t}=\underset{(26.40)}{48.41}-\underset{(21.29)}{22.68(1+\bar{r})} \mathrm{t}_{(0.21)}+\underset{t-1}{0.69 \mathrm{~B}_{t-1} / \mathrm{P}_{t-1}}+\underset{(0.24)}{0.20 \mathrm{~B}_{t-2} / \mathrm{P}_{t-2}} \\
& -1.30 \mathrm{~s}_{t}-0.63 \mathrm{~s}_{t-1} \text {. } \\
& (0.13) \quad(0.31)
\end{aligned}
$$

We took $\bar{r}=0.0112$, the average ex post real rate over $1960-1984$. This equation clearly yields no indication that government debt tends to be growing at rate $\bar{r}_{\xi}$ the coefficient $\hat{A}_{0}$ is statistically insignificant, and, if anything, negative in sign.

(3) Restricted Flood-Garber tegt. The test actually used by Flood and Garber (1980) would be valid for our application only under the further restrictions that $\mathrm{n}_{t}$ follows a white noise process

$$
\mathrm{n}_{\mathrm{t}}=\mathrm{k}+\varepsilon_{1 t}
$$

and that creditors expectations of future surpluses are based solely on past realizations of surpluses. ${ }^{10}$ A straight-forward manipulation of the formula derived by Hansen and Sargent (1981, p. 99) yields that for

$$
S_{t}=k_{2}+a_{1} S_{t-1}+a_{2} S_{t-2}+a_{3} S_{t-3}+\varepsilon_{2 t}
$$

then

$$
\begin{gathered}
\hat{\mathrm{E}}_{t} \sum_{j=1}^{\infty} b^{j} S_{t+j}=\frac{b_{2}}{(1-b)\left(1-a_{1} b-a_{2} b^{2}-a_{3} b^{3}\right)}+\frac{\left(a_{1} b+a_{2} b^{2}+a_{3} b^{3}\right) S_{t}}{\left(1-a_{1} b-a_{2} b^{2}-a_{3} b^{3}\right)} \\
+\frac{\left(a_{2} b+a_{3} b^{2}\right) s_{t-1}}{\left(1-a_{1} b-a_{2} b^{2}-a_{3} b^{3}\right)}+\frac{\left(a_{3} b\right) s_{t-2}}{\left(1-a_{1} b-a_{2} b^{2}-a_{3} b^{3}\right)}
\end{gathered}
$$


where $\hat{E}_{t}(Y) \equiv E\left(Y \mid S_{t}, S_{t-1}, S_{t-2}, \ldots\right)$ and $b \equiv 1 /(1+\bar{r})$, Substituting (16) and (18) into (14) yields

$$
\begin{aligned}
B_{t} / P_{t}=A_{0}(1+\bar{r})^{t} & +k_{1}+\frac{\left(a_{1} b+a_{2} b^{2}+a_{3} b^{3}\right) s_{t}}{\left(1-a_{1} b-a_{2} b^{2}-a_{3} b^{3}\right)}+\frac{\left(a_{2} b+a_{3} b^{2}\right) s_{t-1}}{\left(1-a_{1} b-a_{2} b^{2}-a_{3} b^{3}\right)} \\
& +\frac{\left(a_{3} b\right) s_{t-2}}{\left(1-a_{1} b-a_{2} b^{2}-a_{3} b^{3}\right)}+\varepsilon_{1 t} .
\end{aligned}
$$

We estimated equations (17) and (19) jointly by nonlinear least squares for $t=1963$ to 1984. Parameter estimates and standard errors are summarized in Table 3 .

As in the less restrictive tests above, we note that there seems to be no role whatever for the "bubble" term; $\hat{A}_{0}$ is statistically insignificant, and, if anything, negative. The assumption that bond-holders rationally expected the debt to be paid back in present value terms fits the data better than the assumption that debt has simply accumulated with an ever-growing interest load. Moreover, for these parameter estimates, equation (19) has an $R^{2}$ of 0,53 ; that is, more than half of the observed variance in the market value of real government debt could be explained from a rational-expectations forecast of the discounted value of future surpluses. Note such high explanatory power is achieved despite the fact that all of the other parameters which characterize the dynamics of outstanding debt in equation (19) are tied down by the univariate process for surpluses (17), and such parameters appear in (19) oniy to the extent that they could characterize rational-expectations forecasts of future surpluses. The high $\mathrm{R}^{2}$ is also achieved despite the omission of all of the additional variables besides past surpluses which would be used by agents to forecast future surpluses. 
Of course, to achieve such a fit to the data, the regression is forced to fit strongly negative coefficients in the autoregressive process for surpluses at two- and three-year lags, as the values in Table 3 indicate. Bond-holders must assume that big deficits typically only last a year or two, and will later be balanced out with surpluses. There is indeed moderate support for this position even in a completely unconstrained oLS estimate of the latter regression:

$$
s_{t}=-0.30+0.62 s_{t-1}-0.30 s_{t-2}-0.20 s_{t-3}
$$

The restricted rational-expectations estimates of Table 3 simply exaggerate this feature in the data, Overall, then, the present value hypothesis seems to hold up quite well.

5. Conclusions.

In this paper we have examined the proposition that in order to be able to issue interest-bearing debt, a government must promise to balance its budget in expected present-value terms. We suggested a battery of empirical tests of this proposition, some of which are quite robust with respect to assumptions about the dynamics of variables which are seen by agents but not the econometrician, and others which are highly restrictive. The conclusion from all our tests, however, is the same- the proposition that the government must promise creditors that it will balance the budget in expected present-value terms seems largely consistent with postwar U.S. data.

This result might seem surprising since the official budget accounts register essentially uninterrupted deficits for the United States from 1960 to 1981 . However, the real value of government debt held by the public actually 
fell during this period, indicating that the continuing reported deficits grosssly misstated the true fiscal posture of the government. We suggested an alternative measure of the government deficit which takes into account revenues from monetization and capital gains on gold but excludes interest payments. From the time-series properties of this adjusted deficit series, one can construct a rational-expectations forecast of the present value of future government budget surpluses. Such a forecast series can account for $53 \%$ of the observed variance of real government debt under the assumption that the government budget must be balanced in present-qalue terms, If our conclusion on the limitations of government borrowing is correct, then the prevailing sentiment in Washington that current deficits can continue forever is wrong; the adjusted deficit series must soon turn to surplus. One policy change which could turn the adjusted series to surplus would be a resurgence of money growth. 


\section{REFERENCES}

Aschauer, David A. "Fiscal Policy and Aggregate Demand," American Economic Review 75 (March 1985): 117-127.

Barro, Robert J, Macroeconomics. New York: John Wiley and Sons, 1984. (a) - "The Behavior of U.S. Deficits." NBER Working Paper No, 1309, March 1984. (b)

Blanchard, Olivier J. "Debt, Deficits, and Finite Horizons," Journal of Political Economy 93 (April 1985):223-247.

Blinder, Alan S,, and Solow, Robert M. "Analytical Foundations of Fiscal Policy." In The Economics of Public Finance, pp. 3-115, Washington, D.C. Brookings Institution, 1974.

Buiter, Willem H. "Measurement of the Public Sector Deficit and Its Implications for Policy Evaluation and Design." IMF Staff Papers 30 (June 1983): $306-349$.

- "Measuring Aspects of Fiscal and Financial Policy." NBER Working Paper No. 1332, April 1984.

, and Carmichael, Jeffrey, "Government Debt; Coment." American Economic Review 74 (September 1984): 762-765.

Burbidge, John B. "Government Debt in an Overlapping-Generations Model with Bequests and Gifts." American Economic Review 73 (March 1983): 222-227. - "Government Debt: A Reply." American Economic Review 74 (September 1984): $766-767$.

Carmichael, Jeffrey. "On Barro's Theorem of Debt Neutrality: The Irrelevance of Net Wealth." American Economic Review 72 (March 1982): 202-213. 
Cass, David. "Optimum Growth in an Aggregative Model of Capital Accumulation." Review of Economic Studies 32 (July 1965): 233-240,

Cox, W. Michael. "The Behavior of Treasury Securities; Monthly, 1942-1984," Research Paper No. 8501, Federal Reserve Bank of Dallas, February, 1985. , and Hirschhorn, Eric. "The Market Value of U.S, Government Debt, 19421980." Journal of Monetary Economice 11 (March 1983): 261-272.

Diba, B. T., and Grossman, H. I. "Rational Bubbles in the Price of Gold." NBER Working Paper No, 1300, 1984.

Dickey, David $A_{1}$, and Fuller, Wayne $A_{1}$ "Distribution of the Estimators for Autoregressive Time Series with a Unit Root." Journal of the American Statistical Association 74 (June 1979): 427-431.

Dixit, A. K, The Theory of Equilibrium Growth, Oxford: Oxford University Press, 1976 .

Dornbusch, Rudiger, and Fischer, Stanley, Macroeconomies. Third edition, New York: McGraw-Hill, 1984.

Eaton, Jonathan. "Fiscal Policy, Inflation and the Accumulation of Risky Capital." Review of Economic Studies 48 (July 1981): $434-445$.

Eisner, Robert and Pieper, Paul J. "A New View of the Federal Debt and Budget Deficits." American Economic Review 74 (March 1984): 11-29,

Feldstein, Martin, "Perceived Wealth in Bonds and Social Security; A Comment," Journal of Political Economy 84 (April 1976); 331-336.

Flood, Robert P., and Garber, Peter M, 'Market Fundamentals Versus Price Level Bubbles: The First Tests." Journal of Political Economy 88 (1980): 745-770. Fuller, Wayne A. Introduction to Statistical Time Series, New Yorks John Wiley and Sons, 1976.

Hamilton, James D, and Whiteman, Charles H. "The Observable Implications of 
Self-fulfilling Expectations." Mimeo, University of Virginia, June 1984. (Revised, February 1985). Forthcoming; Journal of Monetary Economies. Hansen, Lars P., and Sargent, Thomas J. "Formulating and Estimating Dynamic Linear Rational Expectations Models." In Rational Expectations and Econometric Practice, edited by Robert E. Lucas, Jr., and Thomas J, Sargent. Minneapolis: University of Minnesota Press, 1981. (Reprinted from Journal of Economic Dynamics and Control, February 1980.)

Jump, Gregory V. "Interest Rates, Inflation Expectations, and Spurious Elements in Measured Real Income and Saving." American Economic Review 70 (December 1980): 990-1004.

McCallum, Bennett T. "Are Bond-Financed Deficits Inflationary? A Ricardian Analysis." - Journal of Political Economy 92 (February 1984): 123-135. Sargent, Thomas J. "The Ends of Four Big Inflations." In Inflation: Causes and Effects, Pp. 41-97. Edited by Robert E, Hall. Chicago: University of Chicago Press, 1982. , and Wallace, Neil. "Some Unpleasant Monetarist Arithmetic." Federal Reserve Bank of Minneapolis Quarterly Review 5 (Fall 1981): $1-17$. Seater, John J, "The Market Value of Outstanding Government Debt, 1919-1975." Journal of Monetary Economics 8 (July 1981): 85-101.

- "Are Future Taxes Discounted?" Journal of Money, Credit and Banking 14 (August 1982): $376-389$.

West, Kenneth. "Speculative Bubbles and Stock Price Volatility." Mimeo, Princeton University, 1984. 
FOOTNOTES

We are indebted to Charles Engel, Ron Michener, and John Taylor for helpful comments, and to Michael Cox for generously providing us with his data.

${ }^{I}$ If government taxes $\left(T_{t}\right)$, spending $\left(G_{t}\right)$ and debt $\left(D_{t}\right)$ are related by $D_{t}+\sum_{j=1}^{\infty}(I+r)^{-j} G_{t+j}=\sum_{j=1}^{\infty}(1+r)^{-j} T_{t+j}$

then any proposal which changes taxes but leaves spending the same must be such that the right-hand side of the above expression remains constant. Thus, permanent disposable income defined by $\sum_{j=1}^{\infty}(1+r)^{-j}\left(w_{t+j} L_{t+j}-T_{t+j}\right)$ would be completely unaffected by any such tax policy. See for example Barro (1984a, pp. 380-381) or Blanchard (1985) for additional details.

2 The more general case of a deficit financed by a mixture of money and different-term bonds is analyzed formally below.

${ }^{3}$ To take a simple example, let output $Q(t)$ grow at the rate $q(Q(t)=$ $\left.Q_{0} e^{q t}\right)$, and let spending $g Q(t)$ and taxes $x Q(t)$ be fixed multiples of GNP. If $r$ is the cost of borrowing and $D(t)$ is the debt, then debt accumulates according to

$$
d D / d t=(g-x) Q(t)+r D(t)
$$

implying

$$
\begin{aligned}
D(t) & =\left\{D_{0}+t Q_{0}(g-x)\right\}^{r t} & & \text { if } q=r \\
& =\{(g-x) /(q-r)\}_{Q_{0}}\left(e^{q t}-e^{r t}\right)+D_{0} e^{r t} & & \text { otherwise }
\end{aligned}
$$

which explodes relative to $Q_{0} e^{q t}$ whenever $g>x$ and $q \leq r$ :

${ }^{4}$ An example of this was provided by Carmichael (1982). See, however, the discussion by Burbidge (1983, 1984) and Buiter and Carmichael (1984). 


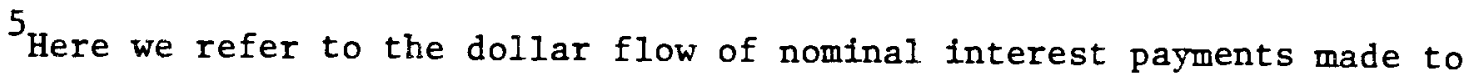
the public divided by the aggregate price level, as distinct from the real user cost of capital which would include capital gains (i,e., use the real interest rate). We use the former interpretation because we are interested in the stock of outstanding government debt, for which purpose the correct expression is the cash-flow identity (4) governing debt accumulation.

6 To take a simple example, suppose that in year 1 spending exceeds taxes by $\$ 1$, with the shortfall made up by $\$ 1$ issue of new agency debt. In all subsequent years, interest spending is $\mathbf{\$ r}$ and taxes are correspondingly higher by $\$ r$. In the accounts as actually reported, this policy would be associated with a $\$ 1$ deficit in year 1 and no surplus in subsequent years. In our proposed measure, by contrast, the deficit is zero in all years: $i . e .$, agency debt has no effect on the present value calculation for Treasury debt, as it should not in this case.

${ }^{7}$ The Export-Import Bank was also originally off-budget, though the accounts were later revised to reflect its current on-budget status,

8 This stationarity test also forms the basis for Diba and Grossman's (1984) investigation of gold price behavior.

${ }^{9}$ Flood and Garber rightly note in their footnote 18 on page 754 that caution must be exercised in interpreting the usual t-test in this application. A related issue of course arises with our Dickey-Fuller tests; if (10) fails, the nonstationary root is not unity as the Dickey-Fuller tests assume but rather $(1+\bar{r})$.

${ }^{10}$ The second assumption in particular is admittedly unrealistic, Indeed, it can be shown that expectations must be based on additional information besides $S_{t}$ (namely, on the exogenous shocks to which the endogenous policy variable $s_{t}$ 


$$
-26-
$$

responds) if equation (14) is to hold, because the forecast errors $\left(E_{t}-E_{t-1}\right) S_{t+j}$ satisfying (14) cannot be fundamental for $S_{t}$. It nevertheless seems of interest to see how good an approximation one gets to the data by ignoring this difference between the true forecasts of creditors $\left(E_{t} S_{t+j}\right)$ and our econometric forecasts $\left(E_{t} S_{t+j}\right)$ based on a univariate autoregression for $S_{t}$. 
Table 1

Illustrative summary of adjustments to officially reported surplus for fiscal year 1974 and for debt at end of fiscal year 1974, in millions of current dollars

\section{SURPLUS:}

Officially reported surplus

Plus: interest

$-\underline{3,460}$

$+28,072$

Minus: interest paid to government trust funds $-6,583$

Minus: deposit of Fed earnings $-4,845$

Plus: change in agency securities $+903$

Equals: Measure of surplus in which interest payments are excluded

Plus: net capital gains on gold stock $+3,250$

Plus: money seignorage $+11,331$

Equals: true surplus (current dollars) $+28,668$

Divided by: consumer price index $\div 1.469$

Equals: true surplus (1967 dollars) $+19,-515$

\section{DEBT:}

Officially reported debt

474,235

Minus: investments in government accounts $-140,194$

Equals: par value of Treasury debt $\underline{334,041}$

Multiplied by: market-par ratio

$$
0.951
$$

Equals: market value of Treasury debt

317,740

Minus: currency in circulation

$-73,833$

Minus: member bank reserves

$-30,086$

Equals: market value of net interest-bearing debt held by public

$\underline{213,821}$ 
Table 1 (continued)

Minus: Treasury operating balance

$-9,159$

Minus: market value of gold holdings

$-39,951$

Equals: adjusted government debt (current dollars)

$\underline{164,711}$

Divided by: consumer price index

$\div 1,469$

Equals: adjusted government debt (1967 dollars)

112,124 
Table 2

Adjusted values for surplus and debt, millions of 1967 dollars

\begin{tabular}{|c|c|c|}
\hline $\begin{array}{l}\text { Fiscal } \\
\text { year }\end{array}$ & $\begin{array}{l}\text { Adjusted surplus } \\
\text { for fiscal year }\end{array}$ & $\begin{array}{l}\text { Adjusted debt for } \\
\text { end of fiscal year }\end{array}$ \\
\hline 1960 & $+8,533$ & 167,954 \\
\hline 1961 & +921 & 170,826 \\
\hline 1962 & $+2,117$ & 176,187 \\
\hline 1963 & $+3,697$ & 177,944 \\
\hline 1964 & $+3,968$ & 176,036 \\
\hline 1965 & $+9,604$ & 173,319 \\
\hline 1966 & $+11,514$ & 160,103 \\
\hline 1967 & $+7,997$ & 157,441 \\
\hline 1968 & $-3,262$ & 162,227 \\
\hline 1969 & $+14,142$ & 144,302 \\
\hline 1970 & $+6,529$ & 136,877 \\
\hline 1971 & $-3,631$ & 145,977 \\
\hline 1972 & $+1,812$ & 151,836 \\
\hline 1973 & $+13,451$ & 136,272 \\
\hline 1974 & $+19,515$ & 112,124 \\
\hline 1975 & $-13,152$ & 134,673 \\
\hline $1976 *$ & $-35,480$ & 185,230 \\
\hline 1977 & $-4,162$ & 191,707 \\
\hline 1978 & $+3,022$ & 183,956 \\
\hline 1979 & $+28,211$ & 148,641 \\
\hline 1980 & $+20,506$ & 121,432 \\
\hline 1981 & $-27,747$ & 145,895 \\
\hline 1982 & $-22,147$ & 209,445 \\
\hline 1983 & $-38,336$ & 265,164 \\
\hline 1984 & $-28,675$ & 303,205 \\
\hline
\end{tabular}

*Data for fiscal year 1976 include the transition quarter (July 1, 1976 through September 30,1976 ). 
Table 3

Estimates of parameters in equations (17) and (19)

$\begin{array}{crc}\text { Parameter } & \text { Estimate } & \text { (Standard error) } \\ \mathrm{A}_{0} & -61.52 & (58.20) \\ \mathrm{k}_{1} & 241.51 & (68.87) \\ \mathrm{k}_{2} & 0.90 & (3.83) \\ \mathrm{a}_{1} & 0.15 & (0.19) \\ \mathrm{a}_{2} & -0.47 & (0,22) \\ \mathrm{a}_{3} & -0.51 & (0,20)\end{array}$

